\title{
Surveillance of Local Government in Fulfilling Community Rights on Social and Environmental Responsibilities
}

\author{
${ }^{1}$ Faculty of Law, Pattimura University, Maluku, Indonesia \\ ${ }^{2}$ Faculty of Law, Hasanuddin University, South Sulawesi, Indonesia
}

Nancy Silvana Haliwela ${ }^{1 *}$, Muhammad Yunus Wahid ${ }^{1}$, Anwar Borahima ${ }^{2}$, Marwati Riza ${ }^{2}$

\author{
DOI: $10.36348 /$ sijlcj.2021.v04i03.001 \\ | Received: 19.02.2021 | Accepted: 02.03.2021 | Published: 06.03.2021
}

*Corresponding author: Nancy Silvana Haliwela

\section{Abstract}

Social and environmental responsibility is based on the presence of investment activities (the corporate) which not only has positive impacts but also negative impacts. The research an empirical-juridical research and examines directly several companies in Maluku Province, Indonesia. The data obtained were analyzed descriptively and qualitatively. The results show that the right of communities is a demand for fulfillment based on legal regulations as a form of responsibility for the obligations of the State or other parties for the interests of an association or association of people who have social interaction relations in a community area within a country. The local government through the surveillance authority guarantees the rights of the community to obtain sources of life so that they do not become lost due to company activities. This protection is through the authority of the local government to supervise CSR activities as the government's responsibility for society and the environment.

Keywords: Corporate Social Responsibility, Community Rights Environmental Law, Local Government.

Copyright $\odot 2021$ The Author(s): This is an open-access article distributed under the terms of the Creative Commons Attribution 4.0 International License (CC BY-NC 4.0) which permits unrestricted use, distribution, and reproduction in any medium for non-commercial use provided the original author and source are credited.

\section{INTRODUCTION}

The implementation of the national economy becomes an obligation of the government to regulate and provide protection for the rights of the people. A government's authority in national economic activities is policy in the investment sector. The arrangement of investment policy by set the regulation on social and environmental responsibility. Global social and environmental responsibility is known as the concept of Corporate Social Responsibility (CSR) [1]. Corporate Social Responsibility (CSR) comes and develops in developed countries and international institutions [2]. CSR as an idea requires companies not to stand on a single bottom line is corporate financial value. But

\footnotetext{
${ }^{1}$ According to the World Bank, CRS as the commitment of business to contribute to sustainable economic development, working with employees and their representatives, their families, the local community and society at large to improve quality of life, in ways that are both good for business and good for development. ${ }^{2}$ Rosser, Andrew, and Donni Edwin. 2020. "The politics of corporate social responsibility in Indonesia." The Pacific Review Vol. 23, no. 1: 1-22.
}

corporate responsibility must be based on the triple bottom line, namely responsibility to the society, the planet and profit.

The movement of corporate social and environmental responsibility is growing rapidly globally based on the principles of eco-development and its principles originating from the 1972 Stockholm declaration, which were then developed into the principles of sustainable development [3]. As for corporations or companies that are part of a nation (corporate citizenship), they have obligations in development. According to the World Economic Forum

\footnotetext{
${ }^{3}$ The concept of sustainability prioritizes growth, especially for the poor in managing their environment and the capacity of their institutions to manage development and the strategy is the ability to integrate economic, ecological and social dimensions that respect ecological and socio-cultural diversity. Then in the development process the three core stakeholders are expected to fully support, namely the corporate government and the community.
} 
Nancy Silvana Haliwela et al., Sch Int J Law Crime Justice, Mar, 2021; 4(3): 130-135

(WEF), corporations or companies must contribute to society, namely [4]:

Corporate citizenship in the contribution a company makes to society and the environment through its core business activities, its social investment and philanthropy programmers, and its engagement in public policy.

Social and environmental responsibility is based on the presence of investment activities (the corporate) which not only has positive impacts but also negative impacts. A fact that the presence of investment (corporate) in the regions will definitely have a negative impact, even though it has benefits for welfare and development can be seen from several cases, including the contract case between NIKE and PT. Naga Sakti Pharama Shoes Indonesia (NASA) and PT. Hardaya Aneka Shoes Indonesia (HASI). By reason of not meeting production quality standards, causes the fate of 14.000 employees was unclear [5].

In this case, a surveillance concept is needed so that the local government can direct the corporate or company regarding the obligation to carry out social and environmental responsibility. Surveillance is known and developed in management science [6]. One of the stresses of surveillance, according to Hendry Fayol is that surveillance is carried out by parties who have the authority, so that procedures can be done on the implementation of social and environmental responsibility. The authority to surveillance is intended as a form of responsibility under the law to get actions and efforts to maximize the achievement of implementation so that it is optimal, right on target and beneficial to the community and the environment. This is to avoid the impact of economic, social and environmental losses.

The Province of Maluku is one of the provinces in the Eastern region of the Republic of Indonesia which has a strategic position, because its position between the West and Central regions of Indonesia and Papua in the East, as well as connecting the South region, namely Australia and Timor Leste with the North region, namely North Maluku and Sulawesi. In addition, Maluku is on an international route, which is traversed by 3 (three) Indonesian Archipelago Sea Lanes (ALKI - Alur Laut Kepulauan Indonesia). This position has a very strategic meaning in the fields of economy, trade and investment.

\footnotetext{
${ }^{4}$ World Economic Forum, Global Corporate Citizenship Initiative, downloaded from http://www.weforum.org/corporatecitizenship

${ }^{5}$ Faisal Basri. 2007. Analisis Ekonomi Baraya Sunda. 30 Agustus 2019.

6 Muchsan. 2000. Sistem Pengawasan Terhadap Perbuatan Aparat Pemerintah dan PTUN di Indonesia. Liberty. Yogyakarta. p. 37
}

The implementation of social and environmental responsibility as regulated in statutory regulations, by Provincial Government of Maluku regulates social and environmental responsibility in the Local Regulation No. 9 of 2014 concerning Guidelines for Corporate Social Responsibility in Maluku Province. The arrangement of surveillance is regulated in Article 23 CHAPTER VII concerning Surveillance, Evaluation and Reporting. Likewise, the Government of Ambon regulates in the Local Government No. 7 of 2017 concerning Corporate Social Responsibility, the provisions of surveillance are regulated in Article 22 CHAPTER VII concerning Surveillance, Evaluation and Reporting.

Surveillance become an attention of the Local Government to be regulated in the Local Regulation on social and environmental responsibility by the Regional Government in Maluku and Ambon, to control the implementation of social and environmental responsibility which is an obligation to be carried out by Limited Liability Companies [7]. Protect community rights due to company activities in the regions and protect non-renewable natural resources for the continuity of future life. Local governments have the authority to regulate and surveillance based on regional autonomy. Therefore, surveillance is an integral part of local government administration. The goal is that the implementation of sustainable development as an effort to realize the welfare and prosperity of the community and the preservation of environmental functions in regional government areas can be realized.

As described above, the research focuses on the concept of local government surveillance in fulfilling the community's rights to social and environmental responsibility by the corporate/company. In addition, analyzing the fulfillment of the Maluku people' rights to social and environmental responsibility by the corporate on a practical level.

\section{Method of Research}

The type of research is an empirical-juridical research [8] and it examines several norms in the legislation related to investment law, the environment, and social and environmental responsibility and examines directly several companies in Maluku Province. The types and sources of data that will be

\footnotetext{
7 Lestari, Intan Belinda, Noradiva Hamzah, and Ruhanita Maelah. 2019. "Corporate Social and Environmental Strategy and Reporting in Indonesian Plantation Industry." Indonesian Journal of Sustainability Accounting and Management, Vol. 3, No. 1: 84-94.

${ }^{8}$ Irwansyah. 2020. Penelitian Hukum: Pilihan Metode \& Praktik Penulisan Artikel. Yogyakarta: Mirra Buana Media, p 203-205
} 
Nancy Silvana Haliwela et al., Sch Int J Law Crime Justice, Mar, 2021; 4(3): 130-135

used as the basis for supporting this research are primary data obtained from the first source of respondents as well as from direct observation in the field, and secondary data obtained from laws and regulations, periodic reports of CSR activities by companies, company data and periodic report on the results of government surveillance. Then, the data obtained were analyzed descriptively and qualitatively.

\section{The Authority of Local Government Surveillance to the Implementation of Social and Environmental Responsibility}

The ruler, in this case the government is given a task to do what is often referred to as bestuurszorg, namely to do a public interest that is done by the ruler (government), where in conducting or administering the public interest, the ruler must have the authority to act [9]. According to Hadjon, authority (bevoegdheid) is described as legal power (rechtsmacht), so that in the concept of public law, authority is related to power [10]. Through this authority, the government can do surveillance. The concept of surveillance is known and developed in management science, because management is part of the organizational function, so it has main functions. One of the main functions in management activities is surveillance. Surveillance is done at every stage and a very important function for achieving the goals of the activities or work. Thus, surveillance becomes an important part of operational activities and becomes an integral part of the implementation of management activities.

Planning, is a basic function (fundamental) of management, planning is the most important aspect in management, good planning will produce the best results, unless there are bad influences from other factors in the process. Planning determines the signs that must be carried out and targets that must be done at each stage until the end and the next stage of an activity. According to Henry Fayol, explained that planning is in the form of determining the initial steps that allow an organization to achieve its goals and is also related to the efforts being carried out to anticipate trends in the future and determine an appropriate strategy or tactic in order to achieve goals.

Organizing, is an activity process based on planning, so that the predetermined plan can run in accordance with what has been stated as planning an activity, can be done with a proportional division of tasks. There is a division of tasks according to the field of activity as an integral part of the organization. Commanding, or leading is a process of direction from parties who are trusted to give direction or orders or

\footnotetext{
${ }^{9}$ Bachsan Mustafa. 2001. Sistem Hukum Administrasi Negara Indonesia.Citra Aditya Bakti. Bandung. p. 26

${ }^{10}$ Ridwan HR. 2008. Hukum Administrasi Negara. PT. RajaGrafindo Persada. Jakarta.p.102
}

even a warning as a leader to human resources (HR), when the activity process is not in accordance with the predetermined and agreed planning. Coordinating, is an act of coordination which means that a relationship is established based on mutual understanding or mutual assistance and together unites and harmonizes all tasks so that activities are directed in order to achieve the goals of an organization. Controlling, is an activity to monitor, prove and ensure that all tasks in an activity that have passed the stages in the previous management function run according to the target and can be properly monitored. In this controlling function, it is useful to ensure that the activities that have been done are in accordance with the original plan and to evaluate them and to provide the correct solution to the problem (solution) to significant (meaningful) deviations [11].

George R. Terry also explained about surveillance in management theory that management is the accomplishing of a predetermined objectives through the efforts of other people, it can be interpreted that management is the achievement of goals that have been set through or together with the efforts of others. Surveillance is an important part of management in any organization, because management is process oriented. So that surveillance becomes one of the variables that are determined as the basis for management, namely; (1) planning, (2) organizing, (3) actuating and (4) controlling [12].

According to George R. Terry in his book Principles of Management states that planning is selecting and relating of facts and the making and using of assumptions regarding the future in the visualization and formulation to proposed of proposed activation believed necessary to achieve desired result, it can be interpreted that planning is choosing facts and connecting facts and actions and using estimates or assumptions for the future by describing and formulating the activities needed to achieve the desired results [13].

According to Henry Fayol and George $\mathrm{R}$ Terry, related to the surveillance of the implementation of social and environmental responsibility by Limited Liability Companies, so that its implementation can be realized and achieved optimally, right on target and can be received by the community and the environment. For this reason, the local government conducts surveillance by implementing the stages of surveillance procedures such as in management activities, as stated by Henry Fayol and Gerge R. Terry, namely; (1) planning, (2)

\footnotetext{
${ }^{11}$ Ibid

${ }^{12}$ Sukarna. 2011. Dasar-Dasar Manajemen. Cv. Mandar Maju. Bandung. p. 10.

${ }^{13}$ Yantje, Liauw and A. Suriyaman M. Pide. 2015. "Adat Law in Designing of Land Law System." JL Pol'y \& Globalization Vol. 40: 41-46.
} 
Nancy Silvana Haliwela et al., Sch Int J Law Crime Justice, Mar, 2021; 4(3): 130-135

organizing, (3) actuating, (4) coordination, and (5) controlling.

Planning is an early stage process for determining goals and objectives to be achieved through social and environmental responsibility activities. It is conducted by the Limited Liability Company, the community and the local government according to their authority. Local governments that can do surveillance activities are the governments at the village, sub-district, district and regency/city or provincial levels that are close to the corporate' operational area. It is prepared by referring to the Local Regulation on Social and Environmental Responsibility. It is conducted jointly, even though the funds for social and environmental responsibility activities belong to the company [14]. However, planning is made together, the goal is to receive input to synergize programs that are prepared to be carried out through social and environmental responsibility so that they are not biased and right on target. Therefore, the results are optimal and produce benefits for society and the environment. The decision and authority regarding the budget and execution time remain the right of the company.

Organizing is surveillance activities that conducted by the local government by creating an organizational structure to bring together companies, as has been established by the local government, namely the establishment of the Forum for Social and Environmental Responsibility. The Social and Environmental Responsibility Forum is not just formed, but it is necessary to optimize activities through this forum. The aim is to become a forum for synergy, not to raise funds for social and environmental responsibility, so that through this forum it can map economic and social development activities that have been included in the local government budget. Thus, those that have not be directed to become targets for the company to do social responsibility activities. The target should be towards the community and the environment around the company. Not for people who are far from the corporate' operational area. The local government maximizes the surveillance at this stage so that the company can have the responsibility to do social and environmental responsibility activities that are right on target, effectively and optimally [15].

\footnotetext{
${ }^{14}$ Murdifin, I., Pelu, M. F. A., Perdana, A. A. H., Putra, K., Arumbarkah, A. M., Muslim, M., \& Rahmah, A. 2019. Environmental disclosure as corporate social responsibility: Evidence from the biggest nickel mining in Indonesia. International journal of Energy Economics and policy, 9(1), 115.

${ }^{15}$ M. Yunus Wahid. 2011. "Prinsip Dan Karakter Hukum Lingkungan." Jurnal Ilmiah Ishlah, Vol. 13, No. 2: 113-126.
}

Commanding, the surveillance of the local government for commanding stage is to provide direction to the Limited Liability Company in accordance with a mutually agreed plan to monitor the implementation of social and environmental responsibility activities by the company. Directions were given so that the company did not deviate from the planning that had been determined to be conducted by responsibility programs to the community and the surrounding environment. Coordination is one of the functions that need to be performed by local government as a form of surveillance. Coordination between local governments and the company and the community were to create synergistic relationships. Communication is indispensable in the coordination process for the implementation of social and environmental responsibility activities. Coordinating activities will be done through social and environmental responsibility programs, so that the implementation is in accordance with the plan and avoids mistakes or deviations from the regulations in the local regulation on Social and Environmental Responsibility.

Controlling is the final stage of surveillance activities conducted by local governments. Surveillance is done to ensure and prove that all social and environmental responsibility activities have been done. Therefore, every activity that has been done is made a report for evaluating, appraising and correcting. This is done as the final stage of the entire series of surveillance of the corporate social and environmental responsibility activities. The results of the evaluation in the form of a report will serve as a reference in formulating policies for subsequent social responsibility activities.

In the legal concept, the regulation of surveillance in local regulation regarding social and environmental responsibility by Limited Liability Companies, by the local government is the most important element which becomes the policy of the local government to regulate. For example, several regions in provinces, districts and cities in Indonesia have included surveillance provisions in the local government on social and environmental responsibility as part of legal oversight of the implementation of corporate social and environmental responsibility.

\section{The Community Rights for the Implementation of Social and Environmental Responsibility by Limited Liability Companies}

Humans by nature have rights and obligations over something in living their social life with other humans. There is no human being who has no rights. The consequence is that the rights of a person result in the obligation of the other party to respect the rights of others. However, each person cannot exercise their rights freely, which can cause harm to others. 
Nancy Silvana Haliwela et al., Sch Int J Law Crime Justice, Mar, 2021; 4(3): 130-135

One of the objectives of the Republic of Indonesia is to protect the entire Indonesian nation. The purpose of this State means that the State guarantees every society as a citizen to obtain rights and obligations for every individual as a member of society and as a citizen. Regarding the rights of people who live and reside in a country, the state has an obligation to fulfill the rights of the people. Demands for the fulfillment of community rights related to government performance, especially those related to government functions and tasks are highly expected by the community [16]. This is often marked by the rampant demonstrations by members of the public regarding the performance of the government which have been disappointing, especially in terms of translating the various aspirations and interests and needs of citizens regarding investment activities.

Community rights are a demand for fulfillment based on legal regulations as a form of responsibility for the obligations of the State or other parties for the interests of an association or association of people who have social interaction relations in a community area within a country. Therefore, in relation to social and environmental responsibility, local governments should guarantee the rights of the community to obtain sources of life so that they do not become lost due to company activities. This form of protection is through the authority of the local government to supervise CSR activities as the government's responsibility towards society and the environment.

Based on an interview with the head of the Legal Bureau of Maluku Province, Hendry Far Far, there have been efforts made by the government to guarantee community rights in terms of social and environmental responsibility by companies. The Provincial government has enacted a regional regulation on social and environmental responsibility (CSR) through the Local Regulation No. 9 of 2014 concerning Guidelines for Social Responsibility of Maluku Province by companies investing in the regions, in accordance with the laws and regulations regarding CSR in Indonesia.

Also, in the regulation by the government regulates surveillance as in the Local Regulation No. 9 of 2014 in Chapter VII regulates the Surveillance, Evaluation and Reporting of the implementation of social and environmental responsibility in the regions. The surveillance arrangement is based on Article 18 paragraph (5) of the 1945 Constitution of the Republic of Indonesia and Act No. 23 of 2014 concerning Local

\footnotetext{
${ }^{16}$ M. Yunus Wahid, Naswar Bohari, and Achmad. 2015. "Penegakan Hukum Lingkungan di Sektor Kehutanan (Studi Kawasan Hutan Lindung di Kabupaten Sinjai, Sulawesi Selatan)." Hasanuddin Law Review Vol. 1, No. 1: 61-73.
}

Government, which gives authority based on autonomy to regional governments, regulating and managing regional potentials to realize community welfare and the preservation of environmental sustainability functions.

As a form of implementation of CSR regulation, the Governor of Maluku Province has stipulated Governor Decree No. 142 of 2019 concerning the Maluku Province Corporate Social Responsibility Forum in 2019. The aim is to accommodate business actors such as state-owned and non-state-owned companies as well as regional companies to carry out supervision of CSR activities by the company.

The results of research showed that the percentage of people who said they did not get attention from related parties about social and environmental responsibility was $61 \%$. In interviews with several communities, it was stated that the community's rights to obtain sources of life did not necessarily disappear as a result of company activities, it's just that local governments have the authority to oversee CSR activities as a form of government responsibility to society and the environment. In fact, the implementation of social and environmental responsibility by the company is not conducted in the area where the company is located.

Meanwhile, the percentage of company responses to stakeholder concerns community rights towards social and environmental responsibility is $80 \%$. Based on the interview, the company claimed to do and conduct CSR as regulated. Meanwhile, the percentage of responses from district government was $71.6 \%$, city government was $72.6 \%$, sub-district government was $73.3 \%$, village government was $72 \%$, and local government was $63 \%$. However, in general all stakeholders are concerned about the rights of the community on the implementation of social and environmental responsibility by limited companies. Comparison of respondents' views about stakeholder concerns regarding community rights to social and environmental responsibility.

The surveillance of CSR is regulated in a local regulation by the local government to protect and provide fulfillment of the rights of local communities, so there needs to be surveillance rules related to CSR activities so that they are useful, optimal, and right on target and so that investment activities do not sacrifice and cause harm to community rights, so that through the CSR program, a symbiotic mutualism or mutually beneficial relationship can be created with all parties, namely the government, society and the company.

The goals and objectives of social and environmental responsibility are for the community and the environment so that the authority of the local government to regulate and conduct surveillance of 
Nancy Silvana Haliwela et al., Sch Int J Law Crime Justice, Mar, 2021; 4(3): 130-135

CSR in the regions so that the presence of investment in the regions does not neglect the rights of local communities, but is fulfilled through CSR activities effectively, optimally and appropriately target. Based on interview, even though there are regulations on supervision of CSR, there has not been any socialization for the government in the areas where the company operates including villages, sub-districts, districts, cities as well as related agencies, communities and companies.

CSR surveillance is conducted by the local government, so that the company can care about community rights. Through CSR activities, the company is directed at community empowerment activities so that it can help efforts to improve the welfare of the local community and preserve the environment. Local governments must also ensure that the CSR programs by the company comply with the laws and regulations governing CSR in Indonesia. So that the CSR program is not solely for the benefit of the business but it is a form of the company's moral and ethical responsibility due to business activities in the local area where the surrounding community experiences the impact of the activities.

\section{CONCLUSION}

The right of communities is a demand for fulfillment based on legal regulations as a form of responsibility for the obligations of the State or other parties for the interests of an association or association of people who have social interaction relations in a community area within a country. The local government through the surveillance authority guarantees the rights of the community to obtain sources of life so that they do not become lost due to company activities. This protection is through the authority of the local government to supervise CSR activities as the government's responsibility for society and the environment. 